\title{
Lean Supply Chains, JIT and Cellular Manufacturing - The Human Side
}

\author{
Irit Alony and Michael Jones \\ University of Wollongong, Wollongong, Australia
}

iritalony@gmail.com; mjones@uow.edu.au

\begin{abstract}
Lean manufacturing has been widely adopted by many production companies. Apart from the operational difficulty associated with conversion from a traditional, functional based operation, adoption of Lean manufacturing involves significant organizational transformations. It requires formation of work teams, comprised of multi-skilled workers. The work teams are preferably self directed and need to continuously improve performance and production processes. Such changes can be challenging for organizations.

This paper reviews studies of human related and organizational factors in the context of Lean manufacturing, and identifies gaps in research in this area. The paper presents the principles of lean manufacturing, the organizational shifts required, and presents studies relevant to each of these shifts. The paper concludes with implications for practitioners and suggestions for further studies.
\end{abstract}

Keywords: Lean manufact uring, Just-in-time, cellular manufacturing, Organizat ional Behaviour.

\section{Introduction}

Lean manufacturing has been the symbol of efficiency and optimal performance since the 1980's, mainly due to its association with the automotive industry and Toyota. It has been shown to outperform the traditional production model of large batches on several occasions (Boyer, Leong, Ward, \& Krajewski, 1997; Nakamura, Sakakibara, \& Schroeder, 1998). Literat ure refers to Lean manufacturing also as "Just-in-time" (JIT), or as "cellular manufact uring" (CM). These terms are often used interchangeably, and the philosophy they describe is the same: elimination of waste, maximization of efficiency, and continuous improvement. Converting into a lean strategy involves both operational changes and, not less challenging, organizational changes.

In 1997, Power and Sohal provided a comprehensive literat ure review of over a hundred articles concerning the human aspects of Just-in-time, cellular manufacturing and lean production. Eight categories of previous studies were identified: corporate culture, organizational structure and the use of team, human resources issues,

Material published as part of this publication, either on-line or in print, is copyrighted by the Informing Science Institute. Permission to make digital or paper copy of part or all of these works for personal or classroomuse is granted without fee provided that the copies are not made or distributed for profit or commercial advantage AND that copies 1) bear this notice in full and 2) give the full citation on the first page. It is permissible to abstract these works so long as credit is given. To copy in all other cases or to republish or to post on a serveror to redistribute to lists requires specific permission and payment of a fee. Contact Publisher@ InformingScience.org to request redistribution permission. employee involvement, education and training, workforce flexibility and the use of kanbans, the impact of changing roles, and lastly, change management strategies (Power \& Sohal, 1997). The authors identified four areas requiring further research: the impact of working in teams, role and import ance of employee flexibility, the impact of education and training, and the effects of 
compensation. Some of these areas have been studied since, and some additional areas related to human aspects of such manufacturing strategies. The aim of this paper is to review these studies, and to identify the areas of additional required research in this field.

\section{Manufacturing Strategies and Organizational Research}

Operational changes alone do not yield expected benefits without a "bundle" which includes struct ural, managerial and cultural changes (Macduffie, 1995). Organizational culture remains one of the main sources of difficulty in conversion to Lean production (Johnson \& Wemmerlov, 2004; Wemmerlov \& Johnson, 1997). Organizational cult ure is also considered a major obstacle in sustaining the potential benefits of Lean production. The link between organizational culture and Lean practices is therefore an import ant area of study.

The importance of aligning organizational culture with operations is widely accepted. Mello and Stank (2005) provide a detailed theoretical framework for dimensions of organizational culture essential for successful supply chain management. According to their framework, supply chains consistent ly comprising companies that maintain trust, commitment, cooperation and top management support, will have better "supply chain orientation" and performance. Although this orientation is not directly linked to Lean production or JIT manufacturing, one of the conditions for a successful Lean strategy is consistency along the supply chain. Thus, these cult ural factors are expected to be critical.

Organizational culture has also been shown to impact on other manufact uring strat egies.

McDermott and Stock (1999) showed different organizational cultures have different levels of managerial satisfaction from advanced manufacturing technologies (AMT). AMT is a production system that includes many lean principles (such as flexible manufacturing systems) as well as computer based technologies supporting the procurement, production and delivery of finished products.

The authors used four types of organizational cultures as described by Quinn and Spreitzer (1991): Hierarchy, Group, Rational and Developmental. The type of culture is determined according to various organizational aspects (such as leadership, organizational glue, control, rewards

etc.) Group culture is characterized by participation, empowerment, teamwork and concern. Hierarchy is typically controlled, formalized and stable. The focus of Group and Hierarchy cultures is internal-aimed at the organization, rather than the environment. A Rational culture is driven by accomplishments and is task focused, efficient and prioritizes quality and efficiency. In a Developmental culture, creativity and flexibility are necessary to sustain changes and growth. Both Rational and Developmental cultures focus on the external environment, in terms of competition and marketing.

The implementation of AMT was perceived to be most valuable for organizations characterized as 'group'. Cultures with an internal focus were negatively correlated with competitive performance, if they adopted AMT, indicating external focus is a better cultural value when AMT is adopted.

This paper starts with presenting the principles of Lean manufacturing. Then, we discuss the human challenges in the adoption of this strategy, by examining existing studies regarding the human aspects of Lean manufacturing. First, we examine the impact of changing into work teams. We then examine the studies on the change into multi-skilled workforce. Studies of self-directed teams are presented next. Further, we explore the human aspects of continuous improvement in Lean manufacturing settings. The paper concludes with suggestions for further research. 


\section{Background - Lean Manufacturing}

Lean manufact uring has been extensively studied. In their book Lean Thinking, Womach and Jones (2003) describe the philosophy, principles, and stages of the implementation of Lean manufacturing. The five principles of Lean presented in Lean Thinking are: (1) value, (2) value stream, (3) flow, (4) pull, and (5) perfection.

(1) Value is defined by the end customer - they are the ones saying what is of value to them. For example, atraveler would see value in getting to their destination on time. (2) The Value Stream is the path the product follows from raw materialto finished product. During this part of the process the product is value-added. For example, a simplistic value stream of wine-making would be growing grapes, harvesting them, crushing them, processing the liquid, bottling the liquid, and shipping it to a store. Each step in the value stream is concerned with adding value to the raw material, when 'value', as explained before, is what the customer sees as important.

(3) The next principle is to make the whole value stream flow. Rather than having the grapes waiting in a storage house to be processes into wine, Lean production is concerned with making sure wine is made as grapes arrive. (4) The fourth principle, pull, regards the initiative for each process. The notion of 'pull' makes the end customer responsible for initiating the production sequence. One only produces what their customer requires. Therefore, a car manufact urer would only make a spare part if one has been ordered through one of the retail shops. One of the practical ways to actualize 'pull', is keeping a set level of inventory, and only buying as much product as has been used or sold. (5) The final principle, perfection, is concerned with a continuous search for causes of waste, and their elimination. Lean strategy recognizes seven kinds of waste, or muda: overproduction, waiting, transport, overprocessing, inventories, movement, and defects.

All these sources of waste are process related. They are controlled by production, layout, and process steps design. However, Human, organizational and behavioural factors also influence the creation of waste.

Womach and Jones provide an action plan which includes mostly operational steps (such as getting the knowledge related to process and Lean, mapping the value stream, dividing the products by families, etc) as well as organizational steps (such as seizing or creating a crisis, begin with a visible activity, demanding immediate results, expand scope once momentum is gained, dealing with anchor-draggers and excess people, etc.). The authors recognize that the implementation of Lean manufact uring involves more than operational changes alone, and describe these steps to assist with a successful transition into a Lean company.

\section{Lean Manufacturing - Organizational Challenges}

The adoption of Lean manufacturing requires a major change in mindset. From production of large quantities, the organization must shift to small batches. Rather than having large safety inventories which act to buffer demand, organizations must retain low levels of 'in-process' material. Processes must be efficient and reliable to avoid defects. Movements of people, parts and material must be minimized. Allthis, in turn, can assist in eliminating the waiting time of material, people, and equipment.

From an organizational perspective, the adoption of Lean manufacturing involves many changes. Structural changes are required, since work needs to be organized around product families instead of functional areas. The workforce has to shift from functional divisions into 'cells' - each cell responsible for the entire manufacturing of a product. This requires a workforce that has the skill to do more than one specialized task - a multi-skilled workforce. Moreover, the multi-skilled operat ors in a cell need to work as a team, and the teams, ideally, need to be self directed. Workers 
need to focus towards a continuous improvement of the process, constantly striving for perfection.

These changes can be difficult to implement. Shifting into work teams means organizational restructuring, which often invokes fear and resistance. Shift ing into multi-skilling can also create resistance in the workers. Although the proponents of Lean manufacturing claim these changes result in an enriched and engaging working environment, studies show the process can be challenging to organizations. Areas of difficulty identified are (1) changing into work teams, (2) developing a multi-skilled workforce, (3) implications of role changes in self-directed teams, and (4) continuous improvement.

\section{Change into Working in Teams}

Since working in teams is an important part of cellular manufacturing, the impact of the conversion of the work environment is an important aspect to study.

\section{Importance of relationships in work teams}

Promotion of teamwork was found to be a necessary condition for successful implementation of JIT flow and quality (McLachlin, 1997). The importance of successful team work has been demonstrated by Banker, Field, Schroeder, and Sinha (1996), in a quant it ative longitudinal case study. The authors compared production, quality, and labour productivity of workers before and after they were divided into teams. The most cohesive team presented with the highest increase in all three measures of performance, whereas the team with the most conflicts did not display any performance improvement. The third team in the study fell between the two extremes both in terms of team relationship and in terms of performance. This study shows the importance of successful team relationships to its operational benefits.

\section{Social interactions in teams}

One of the difficulties in team formations comes from team members' perceptions. Teams in Lean manufact uring involve people who traditionally work in separate, and sometimes hostile, departments. Integrating these individuals into one operating team can result in conflict, as described by Cheddy et al. (1994) in Humphreys, McAleer, and McIvor (1999). This example describes an interaction between an engineer and an operator who were previously members of different organizational units. The two people were made members of the sameteam, however their preconceived ideas about one another sabotage potential collaboration. The engineer perceives operat or's questions as a threat to his authority, whereas the operator perceives the defensive response as being condescending and insulting. This example shows the import ance of socialization for the integration of the various team members. This is consistent with findings of Yauch and Steuel (2002), saying rigid group boundaries are an organizational factor impeding the conversion to cellular manufacturing. This study is described in more detail in the section 3.4.1 below.

\section{Workers perspective}

From the workers perspective, "teamwork" was ranked as one of the most import ant humanrelated fact or in cellular manufacturing companies (Fraser, Harris, \& Luong, 2007). It was found that the more experienced workers (over three years of service) claimed to have more humanrelated problems than technical problems. This was explained by new workers not completely mastering the operational and technical problem, therefore perceiving these challenges as the more prevalent ones. The results of this study show that while the area of expertise becomes an area of comfort with time and experience, the area of human relations remains problematic and needs to be addressed. 
These studies show the import ance of harmonious teamwork, both from operational and from workers perspective. Lean manufact uring has been criticized for imposing a working environment lacking in redundancy, including time and staff redundancies (Delbridge 1998). This has been shown to limit the possibility of constructive human interactions and thus negatively impact relationships between workers. Further study on the most effective methods to facilitate successful teamwork in this environment is required.

\section{Multi-skilled Work Force}

To increase production flexibility, JIT emphasizes the need for multi-skilled employees. This enables dynamic allocation of human resources according to production needs.

\section{Training}

Cross-training, which leads to multi-skilling, has been found to have a significant impact in cellular manufacturing success (Olorunniwo \& Udo 2002). In this study, the authors explain that cross-training increases employee awareness to potential quality problems resulting from machine setup and operation. Another contribution of multi-skilling is sugge sted to be job enrichment as well as facilitation of team work, thus answering the needs for social interactions (Monden 1994; Womack \& Jones 2003).

Training is a key method in establishing multiple skills. It is therefore not surprising that 'training' was ranked as a high-importance subject for cellular-manufacturing employees (Fraser et al. 2007), as well as among managers of cellular manufact uring (McLachlin 1997). Technical and operational training provides workers with the tools to cope with their role-requirements. The importance of this issue justifies the allocation of resources (for financial and non-financial) to promote cross-training.

\section{Organizational context}

Contextual factors also have an effect on multi-skilled, or cross-functional, work force. White, Pearson, and Wilson (1999) found small companies are more likely to have multi-skilled employees than large companies, explaining small companies are more likely to diversify the skills of their work force. Shah and Ward (2003) found no such difference in likelihood. However, compared to other lean practices studied, Shah and Ward found the association of multi-skilled work force and company size was weak. In general, large companies have more resources to enable the implementation of Lean practices, however smaller companies need a multi-skilled work force, to achieve economies.

Shah and Ward (2003) found unionization, as well as plant age, to be negatively correlated with cross-functional work force. A possible explanation for this finding is that both factors are likely to reflect the level of entrenchment of organizat ional culture and behaviour, which inhibit organizational changes.

\section{Incentives}

Karlsson and Ahlstrom (1995) show how multi-skilling can be encouraged through financial incentives. In this study, the number of different skills of an employee was directly linked to their base pay. The effect on employees was observed to have two stages. At first, workers are reluctant to change, in fear of loss of income. The authors describe a drop in productivity, which was partially perceived as a result from change in remuneration. However, employee motivation to learn new team tasks increased, leading to higher team flexibility. This case study demonstrates a way to form a multi-skilled work force. Despite initial resistance, individual employee objectives obtained a closer alignment with the objectives of the company. 
This study does not indicate if the motivation for cross-training led to cross- functional work as well. Various studies show that switching roles is not always 'enriching' for employees, but rather disruptive (Delbridge 1998). The pressure to keep up with time and quality demands encourages workers to preferto specialize at performing a limited number of tasks in order to successfully complete them. Rather than job enrichment, multi-skilling is reported in this study to inflict additional pressure and intensify workload. Further studies are required to determine whether incentives can be used effectively to encourage cross-functional work.

\section{Multi-skilled managers}

Another aspect of multi-skilling is not the multi-skilled worker, but rather the cross-functional manager. McCarter, Fawcett, and Magnan (2005) after interviewing 51 senior level supply chain managers, emphasize the need for managers who have an underst anding of the roles and challenges of the various value-adding activities across the organization.

Multi-skilled workers and managers are a key component of Lean manufacturing organizations. Other than cross functional training, companies can influencethe level of multi-skilling by establishing organizational norms and procedures supporting it. Further research to the impacts of cross-skilled managers is required.

\section{Role Change in Self Directed Teams}

Cellular manufact uring entails a change of role for workers and managers alike. Workers are required to assume more responsibilities whereas managers are required to shift from "policing" to "coaching". This reduction of hierarchical distance due to employee empowerment poses a challenge for both workers and managers. A study of employees reaction to change into selfmanaged work teams showed employees' expectations were critical for their satisfaction and commitment (Shapiro \& Kirkman 1999). According to this study, employees' concerns about undesirable job assignments and added responsibilities led to higher resistance to the change. Managers perceptions and reactions were not measured in this study, thus warranting further studies.

\section{Workers perception}

It is difficult to isolate the influence these aspects of cellular manufacturing have on members involved. Shafer, Tepper, Meredith, and Marsh (1995) compared the job characteristics and attitudes of cellular manufacturing employees, and traditional functional workers. Employees in traditional functional roles reported higher job satisfaction and stronger organizational commitment than cellular manufact uring employees. The same study, however, found indirect favorable impact of cellular manufacturing and employee attitudes. These mixed results indicate cellular manufacturing impacts on employees in more ways than only via job design. The authors suggested reliance on co-workers as a possible factor.

\section{Organizational context}

Self directed work teams have been found to be less common among unionized, old plants (Shah $\&$ Ward 2003). Unionization and plant age are often believed to contribute to entrenchment of habits in an organization, and were found to be more likely to pose organizational barriers to adoption of some lean practices. Company size was not found to inhibit self directed work teams. The study does not reveal which organizational factors, caused by plant age and unionization, impede the adoption of self directed work teams. Further research in this area is required. 


\section{Striving for Perfection - Continuous Improvement}

Many continuous improvement schemes have been adopted by organizations in proximity to Lean manufacturing, such as ISO, Six Si gma, Business Process Renovation (BPR), and TQM. Such cont inuous improvement programs, as suggested by Detret, Schroeder, \& Mauriel (2000), require various supporting cultural values: relying on long-term orientation, belief in intrinsic employee motivation, const ant aspiration for improvement (as opposed to reaching stability), internal process improvement aiming to achieve results, internal and external collaboration and cooperation, and strong customer orientation. Studies reveal the influences of different organizational factors and practices on the perfection aspect of Lean manufacturing.

\section{Impeding factors}

Many organizational factors can impede continuous improvement efforts. A study by Yauch and Steudel (2002) revealed seven organizational factors that impede conversion to cellular manufacturing, and in particular, inhibit continuous improvement of the operation: under-organizing, avoidance, lack of mutual respect and trust, lack of crisis urgency, complacency, rigid group boundaries, and over emphasis on core activities. Under-organization hindered not only the conversion to cellular manufact uring, but also caused waste of time and effort of workers. Avoidance undermined workers motivation to make improvement initiatives, as the organizational culture tends to punish people for mistakes. Lack of mutual respect and trust bet ween workers and management also stops workers form taking improvement initiatives. Crisis urgency (or lack of) and complacency are two inter-related factors, both undermining workers improvement motivation. In the lack of crisis urgency, complacency and resignation with existing problems are accepted. Rigid group boundaries make the flow of information and improvement ideas difficult. Finally, overemphasis on core activities, ratherthan on improving processes or systems, was also found to be a factor negatively influencing continuous improvement.

\section{Supporting factors}

The only factor Yauch and Steudel (2002) identified to have a positive effect on conversion to lean manufacturing is external customer focus. The study found customer orient at ion supported initiatives for change, if the change was to directly affect customer satisfaction. This is consistent with many other studies. In a survey of 224 companies by Nahm, Vonderembse, and Koufteros (2004) showed companies with strong customer orientation values correlate with the adoption of Lean manufacturing, and are positively related to performance.

Financial incentives were also found to impact continuous improvement, as shown by Karlsson and Ahlstrom (1995). In their study, as described above, the remuneration system was changed along with the adoption of Lean production. Apart from a fixed component of employee salary, a bonus component was designed. It depended on the following team achievements: productivity, quality and time accuracy. In this study, productivity was measured as production time compared to standard production time. Quality was measured as number of defects, and only zero-defects resulted in a bonus. Time accuracy was also measured, which is the measure of orders which are delivered on time.

The bonus which was conditioned on zero-defects, had a visible impact on workers focus. It made employees take measures to correct defective parts and avoid their delivery. Employees were observed to become more efficient, not tolerating missing parts, in order to achieve the time accuracy bonus. This demonstrates a possible way to get workers motivation and involvement in improving operations. However, this study only observed a short period of time after the adoption of Lean - a limitation acknowledged by the authors. It may be difficult to maintain constant, unstructured efforts for improvement over longer periods of time. Further research to discover other supporting organizational factors is required. 


\section{Maintenance}

Although preventative maintenance has been identified as critical for a successful implementation and sustainability of JIT (Spencer \& Guide, 1995), evidence show maintenance practices are not adjusted (Swanson, 1999). This is explained by the need for different maintenance practices being less apparent to managers, since JIT does not involve major changes in technology. This lack of attention to maintenance is reflected in the equally poor focus in the literature in this field (Pintelon, Pinjala, \& Vereecke, 2006).

\section{Implication for Practitioners}

Practitioner considering implementing lean manufacturing can benefit from the following guidelines:

\section{Shifting into Work Teams}

Many issues arise from shifting into work teams. While work teams are created in order to leverage collaboration between different professionals, social and human related issues can reduce teams' effectiveness. The social side of work teams is critical both for operational performance and for sustaining the benefits of lean manufacturing. It is therefore critical to address communication to achieve a functional social environment.

\section{Multi-Skilled Workforce}

Since unionized, older plants have been found to be negatively associated with cross-functional workforce, practitioners in such plants aiming to establish such norms can expect more difficulties than in plants that are not unionized and younger. For a successful implementation, more attention and resources will be required.

It is also important to revise incentives schemes, so they reflect the priority of cross-functional training, as well as cross-functional work. Incentives can be financial (for example, increased pay rate for greater number of skills) as well as non financial (for example, associat ing promotion with cross training).

Leading by example is another way to promote a multi-skilled work force. Multi skilled managers can serve as role models for employees.

\section{Self Directed Teams}

Employees' expectations of injustice as a result of shifting into work teams (rather than injustice it self) can be a source of employee resistance to this change. Providing reasonable explanations for these changes was not found to be sufficient to alleviate these concerns. Such concerns and expectations need to be identified in advance and addressed before and during change implementation.

\section{Continuous Improvement}

Certain organizational fact ors need to be identified and addressed in orderto achieve cont inuous improvement mindset. These factors are: under-organizing, avoidance, lack of mut ual respect and trust, complacency, rigid group boundaries, and over emphasis on core activities. In contrast, the following organizational factors should be nurtured in order to support continuous improvement mindset in organizations: crisis urgency, external customer focus, and an alignment of the financial incentive scheme to encourage improvement activities. 
Maintenance practices also need to be revised, to align with production needs, as well as to provide additional source of improved performance.

\section{Conclusion and Further Research}

This paper has explored the factors which contribute to the successful and efficient adoption of Lean manufacturing. Companies which adopt Lean production will need to implement an organizational and cultural change during the process. This change will have measurable and immeasurable effects on the staff. Some of the measures that need to be implemented and their effects are discussed.

Much of the work in understanding the process and effects of this type of organizational change is yet to be done. Much more research is needed to more comprehensively capture and explain all of the variations involved in supply chain management, especially when organizational change is involved. The following questions for further research are suggested:

- What methods can be used effectively to establish harmonious work teams in organizations adopting lean manufact uring?

- How do company's age and unionization status influence the adoption of lean practices?

- What are the reactions of managers to formation of self-directed work teams?

- How can the role change in self-directed work teams be supported in an organization adopting lean manufacturing?

- How do cross-skilled managers influence the operation and performance of lean organizations?

- Can incentives be used to encourage cross-functional work, and how?

- What other organizational fact ors support the adoption of lean manufact uring, besides customer focus and aligned incentive scheme?

- How are these organizational issues different in the lean context?

Although lean manufacturing is seen as an 'old-fashioned' concept by some industries, the adoption of lean practices remains relevant. Organizations which have so far failed to adjust to lean philosophy may not have a choice in today's globally competitive world. Therefore, the harder cases of lean adoption may need to have some of these issues brought to light.

\section{References}

Banker, R. D., Field, J. M., Schroeder, R. G., \& Sinha, K. K. (1996). Impact of work teams on manufacturing performance: A longitudinal field study. The Academy of Management Journal, 39(4), 867-890.

Boyer, K. K., Leong, G. K., Ward, P. T., \& Krajewski, L J. (1997). Unlocking the potential of advanced manu facturing technologies. Journal of Operations Management, 15(4), 331-347.

Delbridge, R. (1998). Life on the line in contemporary manufacturing: The workplace experience of lean production and the" Japanese" model. Oxford University Press.

Detert, J. R., Schroeder, R. G., \& Mauriel, J. J. (2000). A framework for linking culture and improvement initiatives in organizations. The Academy of Management Review, 25(4), 850-863.

Fraser, K., Harris, H. \& Luong, L (2007). Team-based cellular manu facturing: A review and survey to identify important social factors. Journal of Manufacturing Technology Management, 18(6), 714-730. 
Humphreys, P. K., McAleer, W. E., \& McIvor, R. T. (1999). New roles for twenty-first century manufacturing. Proceedings of the Institution of Mechanical Engineers, Part B: Journal of Engineering Manufacture, 213(3), 215-224.

Johnson, D. J., \& Wemmerlov, U. (2004). Why does cell implementation stop? Factors influencing cell penetration in manufacturing plants. Production and Operations Management, 13(3), 272-89.

Karlsson, C., \& Åhlström, P. (1995). Change processes towards lean production: The role of the remuneration system. Change, 15, 11.

Macduffie, J. P. (1995). Human resource bundles and manufacturing performance: Organizational logic and flexible production systems in the world auto industry. Industrial and Labor Relations Review, $48(2), 197-221$.

McCarter, M. W., Fawcett, S. E., \& Magnan, G. M. (2005). The effect of people on the supply chain world: Some overlooked issues. Human Systems Management, 24(3), 197-208.

McDermott, C. M., \& Stock, G. N. (1999). Organizational culture and advanced manufacturing technology implementation. Journal of Operations Management, 17(5), 521-533.

McLachlin, R. (1997). Management initiatives and just-in-time manufacturing. Journal of Operations Management, 15(4), 271-292.

Mello, J. E., \& Stank, T. P. (2005). Linking firm culture and orientation to supply chain success. International Journal of Physical Distribution \& Logistics Management, 35(8), 542-554.

Monden, Y. (1994). Toyota production system. London: Chapman and Hall.

Nahm, A. Y., Vonderembse, M. A., \& Koufteros, X. A. (2004). The impact of organizational culture on time-based manu facturing and performance. Decision Sciences, 35(4), 579-607.

Nakamura, M., Sakakibara, S., \& Schroeder, R. G. (1998). Adoption of just-in-time manufacturing methods at US- and Japanese-owned plants: Some empirical evidence. IEEE Transactions on Engineering Management, 45(3), 230-240.

Olorunniwo, F., \& Udo, G. (2002). The impact of managem ent and employees on cellular manu facturing implementation. International Journal of Production Economics, 76(1), 27-38.

Pintelon, L., Pinjala, S. K., \& Vereecke, A. (2006). Evaluating the effectiven ess of mainten ance strat egies. Journal of Quality in Maintenance Engineering, 12(1), 7-20.

Power, D. J., \& Sohal, A. S. (1997). An examination of the literature relating to issues affecting the human variable in just-in-time environments. Technovation, 17(11-12), 649-666.

Quinn, R. E., \& Spreitzer, G. M. (1991). The psychometrics of the competing values culture instrument and an analysis of the impact of org anizational culture on quality of life. Research in Organizational Change and Development, 5, 115-142.

Shafer, S. M., Tepper, B. J., Meredith, J. R., \& Marsh, R. F. (1995). Comparing the effects of cellular and functional manu facturing on employees' perceptions and attitudes. Journal of Operations Management, 12(2), 63-74.

Shah, R., \& Ward, P.T. (2003). Lean manufacturing: Context, practice bundles, and perform ance. Journal of Operations Management, 21(2), 129-149.

Shapiro, D. L., \& Kirkman, B. L. (1999). Employees' reaction to the change to work teams. Journal of Organizational Change Management, 12(1), 51-67.

Spencer, M. S., \& Guide, V. D. (1995). An exploration of the components of JIT Case study and survey results. International Journal of Operations \& Production Management, 15(5), 72-83.

Swanson, L. (1999). The impact of new production technologies on the maintenance function: An empirical study. International Journal of Production Research, 37(4), 849-869. 
Wemmerlov, U., \& Johnson, D. J. (1997). Cellular manufacturing at 46 user plants: Implementation experiences and performance improvements. International Journal of Production Research, 35(1), 29-49.

White, R. E., Pearson, J. N., \& Wilson, J. R. (1999). JIT manufacturing: A survey of implementations in small and large US manufacturers. Management Science, 45(1), 1-15.

Womack, J. P., \& Jones, D. T. (2003). Lean thinking: Banish waste and create wealth in your corporation. Free Press.

Yauch, C. A., \& Steudel, H. J. (2002). Cellular manufacturing for small businesses: Key cultural factors that impact the conversion process. Journal of Operations Management, 20(5), 593-617.

\section{Biographies}

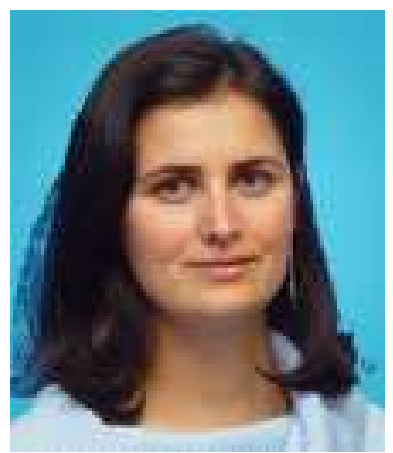

Irit Alony. BCSc; Grad.Cert. (Comp Sc.); MIS. Irit is a PhD student in the faculty of Informatics at the University of Wollongong. Her subject is the influence of organizational factors on operational decision making. She has been an academic teaching and researching in areas of information systems, knowledge management, and communication and culture for three years both at the University of Wollongong and at Central Queensland University. Irit has developed research interests in the following areas: organizational behaviour, decision making, organizational culture, and knowledge management. Irit is also developing research strengths in areas of qualitative analysis.

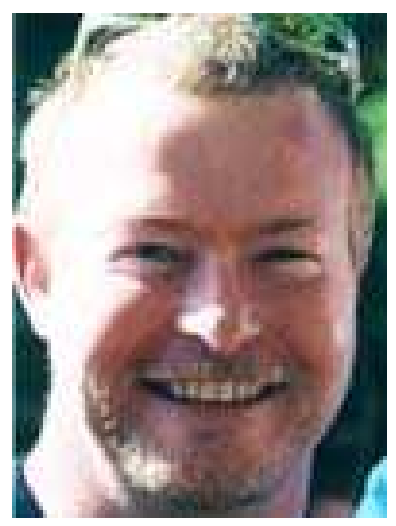

Mich ael Jones. BComm (hons), PhD. Michael has been an academic teaching and researching in areas of organisation, business and management for nine years. Michael has developed research interests in the following areas: organisational psychology and behaviour - looking at commitment and motivation and group dynamics. Michael is also developing research strengths in areas of qualitative analysis and has written several papers on various qualitative methodologies and methods. Michael is also interested in research areas such as knowledge management and organisational leaming. Michael is also a coinvestigator on a major research project explore compet itive analysis in the Australian Marine Industry.

Michael is a member of the Australia and New Zealand Academy of Management, the Australian Human Resources Institute, and the Industrial Relations Society of Australia. 